for conservation globally

Threatened

通
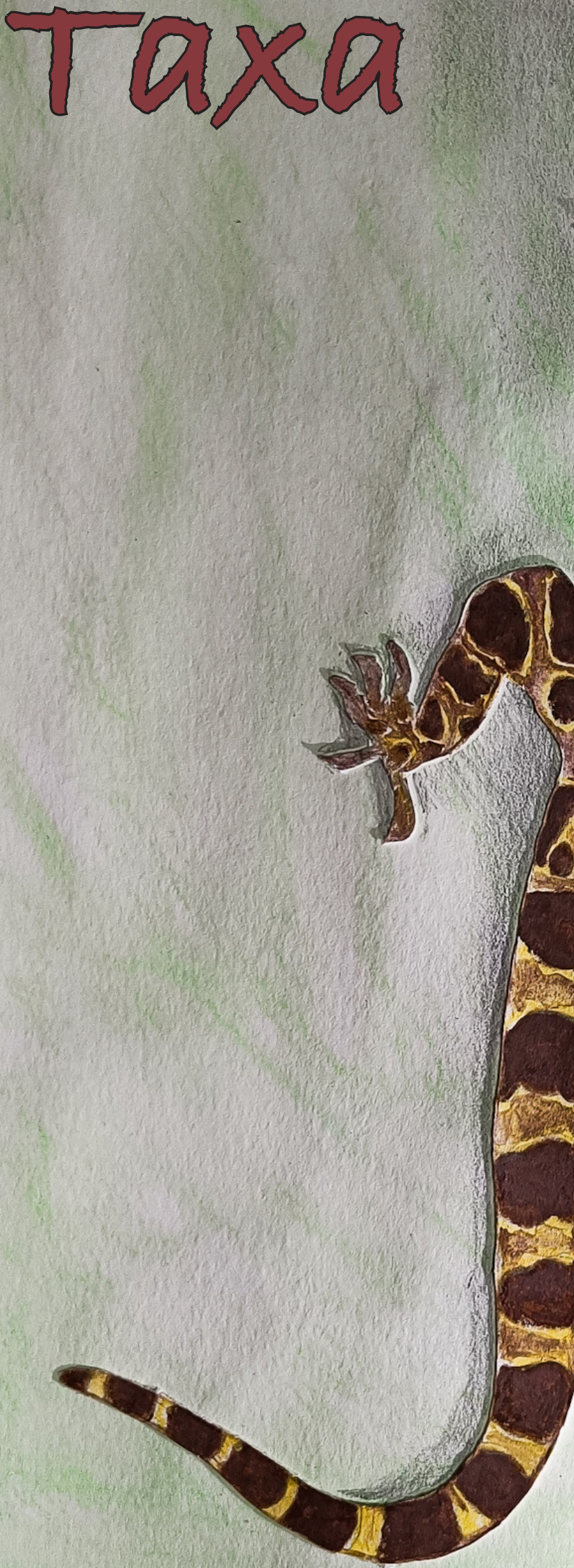

Open Access



$10.1160 \mathrm{~g} / \mathrm{j}$ ott.2022.14.1.20311-20538 wWw.threatenedtaxa.org

26 January 2022 (Online \& Print) 14(1): 20311-20538 ISSN0974-7907 (Online) ISSN 0974-7893 (Print) 


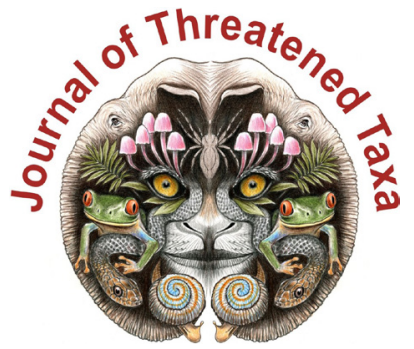

ISSN 0974-7907 (Online); ISSN $0974-7893$ (Print)

Publisher

Host

Wildlife Information Liaison Development Society

www.wild.zooreach.org

Zoo Outreach Organization www.zooreach.org

No. 12, Thiruvannamalai Nagar, Saravanampatti - Kalapatti Road, Saravanampatti, Coimbatore, Tamil Nadu 641035, India

Ph: +91 9385339863 | www.threatenedtaxa.org

Email: sanjay@threatenedtaxa.org

EDITORS

\section{Founder \& Chief Editor}

Dr. Sanjay Molur

Wildlife Information Liaison Development (WILD) Society \& Zoo Outreach Organization (ZOO),

12 Thiruvannamalai Nagar, Saravanampatti, Coimbatore, Tamil Nadu 641035, India

\section{Deputy Chief Editor}

Dr. Neelesh Dahanukar

Noida, Uttar Pradesh, India

\section{Managing Editor}

Mr. B. Ravichandran, WILD/ZOO, Coimbatore, India

\section{Associate Editors}

Dr. Mandar Paingankar, Government Science College Gadchiroli, Maharashtra 442605, India

Dr. Ulrike Streicher, Wildlife Veterinarian, Eugene, Oregon, USA

Ms. Priyanka Iyer, ZOO/WILD, Coimbatore, Tamil Nadu 641035, India

Dr. B.A. Daniel, ZOO/WILD, Coimbatore, Tamil Nadu 641035, India

\section{Editorial Board}

Dr. Russel Mittermeier

Executive Vice Chair, Conservation International, Arlington, Virginia 22202, USA

\section{Prof. Mewa Singh Ph.D., FASc, FNA, FNASc, FNAPsy}

Ramanna Fellow and Life-Long Distinguished Professor, Biopsychology Laboratory, and Institute of Excellence, University of Mysore, Mysuru, Karnataka 570006, India; Honorary Professor, Jawaharlal Nehru Centre for Advanced Scientific Research, Bangalore; and Adjunct Professor, National Institute of Advanced Studies, Bangalore

\section{Stephen D. Nash}

Scientific Illustrator, Conservation International, Dept. of Anatomical Sciences, Health Sciences Center, T-8, Room 045, Stony Brook University, Stony Brook, NY 11794-8081, USA

\section{Dr. Fred Pluthero}

Toronto, Canada

\section{Dr. Priya Davidar}

Sigur Nature Trust, Chadapatti, Mavinhalla PO, Nilgiris, Tamil Nadu 643223, India

\section{Dr. Martin Fisher}

Senior Associate Professor, Battcock Centre for Experimental Astrophysics, Cavendish

Laboratory, JJ Thomson Avenue, Cambridge CB3 OHE, UK

\section{Dr. John Fellowes}

Honorary Assistant Professor, The Kadoorie Institute, 8/F, T.T. Tsui Building, The University of Hong Kong, Pokfulam Road, Hong Kong

\section{Prof. Dr. Mirco Solé}

Universidade Estadual de Santa Cruz, Departamento de Ciências Biológicas, Vice-coordenado do Programa de Pós-Graduação em Zoologia, Rodovia Ilhéus/Itabuna, Km 16 (45662-000)

Salobrinho, Ilhéus - Bahia - Brasil

\section{Dr. Rajeev Raghavan}

Professor of Taxonomy, Kerala University of Fisheries \& Ocean Studies, Kochi, Kerala, India

\section{English Editors}

Mrs. Mira Bhojwani, Pune, India

Dr. Fred Pluthero, Toronto, Canad

Mr. P. Ilangovan, Chennai, India

Web Development

Mrs. Latha G. Ravikumar, ZOO/WILD, Coimbatore, India

\section{Typesetting}

Mr. Arul Jagadish, ZOO, Coimbatore, India

Mrs. Radhika, ZOO, Coimbatore, India

Mrs. Geetha, ZOO, Coimbatore India
Fundraising/Communications

Mrs. Payal B. Molur, Coimbatore, India

Subject Editors 2018-2020

Fungi

Dr. B. Shivaraju, Bengaluru, Karnataka, India

Dr. R.K. Verma, Tropical Forest Research Institute, Jabalpur, India

Dr. Vatsavaya S. Raju, Kakatiay University, Warangal, Andhra Pradesh, India

Dr. M. Krishnappa, Jnana Sahyadri, Kuvempu University, Shimoga, Karnataka, India

Dr. K.R. Sridhar, Mangalore University, Mangalagangotri, Mangalore, Karnataka, India

Dr. Gunjan Biswas, Vidyasagar University, Midnapore, West Bengal, India

\section{Plants}

Dr. G.P. Sinha, Botanical Survey of India, Allahabad, India

Dr. N.P. Balakrishnan, Ret. Joint Director, BSI, Coimbatore, India

Dr. Shonil Bhagwat, Open University and University of Oxford, UK

Prof. D.J. Bhat, Retd. Professor, Goa University, Goa, India

Dr. Ferdinando Boero, Università del Salento, Lecce, Italy

Dr. Dale R. Calder, Royal Ontaro Museum, Toronto, Ontario, Canada

Dr. Cleofas Cervancia, Univ. of Philippines Los Baños College Laguna, Philippines

Dr. F.B. Vincent Florens, University of Mauritius, Mauritius

Dr. Merlin Franco, Curtin University, Malaysia

Dr. V. Irudayaraj, St. Xavier's College, Palayamkottai, Tamil Nadu, India

Dr. B.S. Kholia, Botanical Survey of India, Gangtok, Sikkim, India

Dr. Pankaj Kumar, Kadoorie Farm and Botanic Garden Corporation, Hong Kong S.A.R., China

Dr. V. Sampath Kumar, Botanical Survey of India, Howrah, West Bengal, India

Dr. A.J. Solomon Raju, Andhra University, Visakhapatnam, India

Dr. Vijayasankar Raman, University of Mississippi, USA

Dr. B. Ravi Prasad Rao, Sri Krishnadevaraya University, Anantpur, India

Dr. K. Ravikumar, FRLHT, Bengaluru, Karnataka, India

Dr. Aparna Watve, Pune, Maharashtra, India

Dr. Qiang Liu, Xishuangbanna Tropical Botanical Garden, Yunnan, China

Dr. Noor Azhar Mohamed Shazili, Universiti Malaysia Terengganu, Kuala Terengganu, Malaysia

Dr. M.K. Vasudeva Rao, Shiv Ranjani Housing Society, Pune, Maharashtra, India

Prof. A.J. Solomon Raju, Andhra University, Visakhapatnam, India

Dr. Mandar Datar, Agharkar Research Institute, Pune, Maharashtra, India

Dr. M.K. Janarthanam, Goa University, Goa, India

Dr. K. Karthigeyan, Botanical Survey of India, India

Dr. Errol Vela, University of Montpellier, Montpellier, France

Dr. P. Lakshminarasimhan, Botanical Survey of India, Howrah, India

Dr. Larry R. Noblick, Montgomery Botanical Center, Miami, USA

Dr. K. Haridasan, Pallavur, Palakkad District, Kerala, India

Dr. Analinda Manila-Fajard, University of the Philippines Los Banos, Laguna, Philippines

Dr. P.A. Sinu, Central University of Kerala, Kasaragod, Kerala, India

Dr. Afroz Alam, Banasthali Vidyapith (accredited A grade by NAAC), Rajasthan, India

Dr. K.P. Rajesh, Zamorin's Guruvayurappan College, GA College PO, Kozhikode, Kerala, India

Dr. David E. Boufford, Harvard University Herbaria, Cambridge, MA 02138-2020, USA

Dr. Ritesh Kumar Choudhary, Agharkar Research Institute, Pune, Maharashtra, India

Dr. Navendu Page, Wildlife Institute of India, Chandrabani, Dehradun, Uttarakhand, India

\section{Invertebrates}

Dr. R.K. Avasthi, Rohtak University, Haryana, India

Dr. D.B. Bastawade, Maharashtra, India

Dr. Partha Pratim Bhattacharjee, Tripura University, Suryamaninagar, India

Dr. Kailash Chandra, Zoological Survey of India, Jabalpur, Madhya Pradesh, India

Dr. Ansie Dippenaar-Schoeman, University of Pretoria, Queenswood, South Africa

Dr. Rory Dow, National Museum of natural History Naturalis, The Netherlands

Dr. Brian Fisher, California Academy of Sciences, USA

Dr. Richard Gallon, llandudno, North Wales, LL30 1UP

Dr. Hemant V. Ghate, Modern College, Pune, India

Dr. M. Monwar Hossain, Jahangirnagar University, Dhaka, Bangladesh

Mr. Jatishwor Singh Irungbam, Biology Centre CAS, Branišovská, Czech Republic.

Dr. Ian J. Kitching, Natural History Museum, Cromwell Road, UK

Dr. George Mathew, Kerala Forest Research Institute, Peechi, India

For Focus, Scope, Aims, and Policies, visit https://threatenedtaxa.org/index.php/JoTT/aims_scope
For Article Submission Guidelines, visit https://threatenedtaxa.org/index.php/JoTT/about/submissions
For Policies against Scientific Misconduct, visit https://threatenedtaxa.org/index.php/JoTT/policies_various

continued on the back inside cover 
.

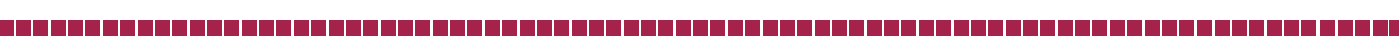

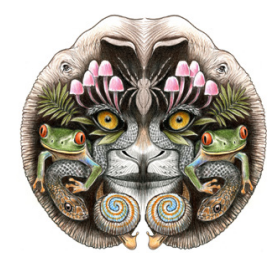

\title{
Plant diversity of Point Calimere Wildlife Sanctuary and fodder species grazed by the Blackbuck Antilope cervicapra L.
}

\author{
Ashutosh Kumar Upadhyay ${ }^{1}$ (D) , A. Andrew Emmanuel ${ }^{2}$ (D) Ansa Sarah Varghese ${ }^{3}$ (D) \& D. Narasimhan ${ }^{4}$ (D) \\ ${ }^{1}$ Central National Herbarium, Botanical Survey of India, Acharya Jagdish Chandra Bose Indian Botanic Garden, Howrah, \\ West Bengal 711103, India. \\ ${ }^{2}$ Door No. 1, Block-I, Met Quarters, College Road, Chennai, Tamil Nadu 600006, India. \\ ${ }^{3}$ Inchackal (H), Cherukole, P.O, Mavelikara, Alappuzha, Kerala 690104, India. \\ ${ }^{4}$ Department of Botany, Madras Christian College (Autonomous) Tambaram, Tamil Nadu 600059, India. \\ ${ }^{1}$ ashutoshpdh196@gmail.com (corresponding author), ²emmanuel.andrew29@gmail.com, ${ }^{3}$ ansa.svarghese@gmail.com, \\ ${ }^{4}$ narasimhand@gmail.com
}

\begin{abstract}
A rapid but intense survey was conducted using visual landmarks in the Point Calimere Wildlife Sanctuary to enumerate the flora and foraging habits of the Blackbuck Antelope cervicapra. The area was divided into various segments such as the sanctuary entrance, Maattu muni kovil, Savukku plot or Casuarina plantation, S-Bend road and the old light house for precise enumeration. A total of 111 plant species that include 50 herbs, 16 climbers/lianas, 30 shrubs and sub-shrubs, and 15 trees belonging to 39 plant families were recorded in this study. Visual observations showed that Blackbucks grazed on grasses such as the Mangrove Grass Aeluropus lagopoides (L.) Thwaites, Dog's Tooth Grass Cynodon barberi Rang. \& Tadul., Indian Durva Grass Cynodon dactylon (L.) Pers., Feather Finger Grass Chloris virgata Sw., and a sedge, the pointed fimbristylis Fimbristylis acuminata Vahl during the day time. They were also observed browsing on the leaves and pods of Algaroba Prosopis juliflora (Sw.) DC. in the evenings. Our observation on the presence of feral horses and stray cattle in the Point Calimere Wildlife Sanctuary shows that they compete for food and water with the Blackbuck. The spread of invasive alien plant species competes with and reduces the space for native species.
\end{abstract}

Keywords: Feral, foraging habits, Nagapattinam District, tropical dry evergreen forests, Fodder species, alien species, habitat, survey, Bishnoi community.

Editor: L.A.K. Singh, Bhubaneswar, Odisha, India.

Date of publication: 26 January 2022 (online \& print)

Citation: Upadhyay, A.K., A.A. Emmanuel, A.S. Varghese \& D. Narasimhan (2022). Plant diversity of Point Calimere Wildlife Sanctuary and fodder species grazed by the Blackbuck Antilope cervicapra L.. Journal of Threatened Taxa 14(1): 20433-20443. https://doi.org/10.11609/jott.5942.14.1.20433-20443

Copyright: (C) Upadhyay et al. 2022. Creative Commons Attribution 4.0 International License. JoTT allows unrestricted use, reproduction, and distribution of this article in any medium by providing adequate credit to the author(s) and the source of publication.

Funding: None.

Competing interests: The authors declare no competing interests.

Author details: Mr. ASHUTOSH KUMAR UPADHYAY has worked in University of Agricultural Sciences (GKVK) as a Junior Research Fellow and in Botanical Survey of India as Senior Research Fellow. He was recently working on the Taxonomy and Ethnobotany of Elatostema J.R.Forster \& G.Forster in India. MR. A. ANDREW EMMANUEL has a master's degree from Madras Christian College in Botany and a degree in Education. He is interested in plant ecology and plant-animal interaction. Currently he is a teacher handling Biology and Biotechnology. MS. ANSA SARAH VARGHESE has worked on the Flora of Rishi Valley School, Andhra Pradesh and has good knowledge of Angiosperm taxonomy. She has also been part of several research programs on Plant breeding at ICAR-IIHR. DR. D. NARASIMHAN is a retired Head of Department of Botany, Madras Christian College. During his tenure he worked extensively towards botanising various parts of India. He currently is a member of Tamil Nadu State Biodiversity Board.

Author contributions: AKU, AAE and ASV were involved in the field survey, identification of plants and preparation of the manuscript. DN supervised the work and gave important inputs for the study. All authors contributed towards writing the manuscript.

Acknowledgements: The authors wish to thank Mr. S. Soundarajan, IFS, wildlife warden (Retd.), Nagapattinam District for facilitating us to carry out the study. We would like to thank Mr. Leslie Lawrence, assistant professor, Department of Botany, Madras Christian College and Dr. Sheeba J. Irwin for their help during the study. We also extend our gratitude to all the field personnel of Point Calimere Bird and Wildlife Sanctuary for their involved help during the field studies. AKU would also like to thank the Director, Botanical Survey of India for providing lab facilities.

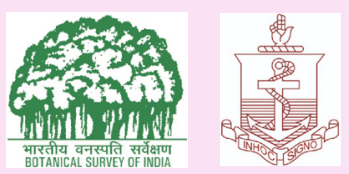




\section{INTRODUCTION}

Point Calimere Wildlife Sanctuary harbours a rich diversity of animals, among them is the Blackbuck which is the most exquisite animal in the sanctuary. The name Blackbuck is in reference to the dark-coloured coat of the adult male which varies from dark brown to black. The belly and hind side of the legs are white. The horns of the males are ridged and twisted. Blackbuck Antilope cervicapra L. is listed under Schedule I, Part I of the Indian Wildlife Protection Act, 1972. Habitats of the Blackbuck have been declared as protected areas in several parts of India, with the support of the local people. Punjab and Haryana have honoured the animal as their state animal (Hundal 2004) and the Bishnoi community of Rajasthan considers the blackbuck as a sacred animal. There are six protected areas in Tamil Nadu where Blackbucks occur in considerable numbers. They include: (a) the Guindy National Park and its contiguous campuses such as Raj Bhavan and the Indian Institute of Technology, Madras (IIT-M), though these campuses do not fall under the protected category; (b) Vallanadu Sanctuary, Tuticorin; (c) Point Calimere Wildlife Sanctuary, Kodiakkarai; (d) Sathyamangalam Wildlife Sanctuary and Tiger Reserve, Erode; (e) Kanyakumari Wildlife Sanctuary, Kanyakumari; and (f) Mudumalai Wildlife Sanctuary and National Park, Nilgiris.

Blackbucks are sensitive and get disturbed by human presence. They prefer open grasslands and like to graze during early mornings and late afternoons. There are no direct predators for the Blackbucks in the Point Calimere Wildlife Sanctuary (PCWS). A census conducted in 2015 by the forest department, Tamil Nadu in coalition with the A.V.C Engineering College, Mayiladuthurai and Government Arts and Science College, Poompuhar recorded 948 Blackbucks, 172 feral horses, 82 Wild Boars, 12 Black-naped Hares, and 20 Jackals in the sanctuary (Suresh 2015). The objectives of this study were (a) to survey the plant diversity and highlight the species of herbs, shrubs, and trees seen in PCWS and (b) to document the grasses and other plant species grazed by the Blackbucks.

\section{MATERIALS AND METHODS}

\section{Study area}

PCWS is one of the largest tropical dry evergreen forests (TDEF) in India located between $10.2878^{\circ} \mathrm{N}$ \& $79.8651^{\circ} \mathrm{E}$ with an expanse of 1,729 ha located in the Nagapattinam district of Tamil Nadu (Figure 1) (Ali
2005; Parthasarthy et al. 2015). TDEF are the areas of vegetation without a distinct differentiation between the small and canopy forming trees, having coriaceous leaves with an average height of less than $12 \mathrm{~m}$, having a luxuriant growth of lianas and climbers along with an inconspicuous presence of grasses (Champion \& Seth 1968; Parthasarthy et al. 2015). This vegetation receives both summer and winter monsoons due to depressions and cyclones in the Bay of Bengal (MeherHomji 1974). It forms an interface between the coastal and the deciduous vegetation, having varied ecosystems with a visible change in the soil type from sandy, saline to alluvial.

Point Calimere was declared a wildlife sanctuary in 1967 for conserving the Blackbuck population that was dwindling due to intensive poaching and hunting (Baruah 2005). PCWS is bordered by Vedaraniyam salt pans in the north, Palk Strait in the south, Bay of Bengal in the east, and Kodiakadu in the west. It gets its name from the point at which both the Bay of Bengal and the Palk Strait meet. The human habitations around the forest are found mainly in two villages namely, Kodiakkarai and Kodiakadu. The sanctuary is an island which is connected to the mainland by the Vedaraniyam-Kodiakkarai road.

\section{Data collection and analyses}

The methods of assessment used were very simple and based on visual observations in the field, i.e., observing Blackbucks while they grazed, followed by visiting the grazing sites to identify the plant species (Altman 1974). Since, this was a rapid survey, methods such as quadrates and other indices were not planned for in the study. However, the sanctuary was divided into the following segments using visual landmarks for effective and efficient data collection: (a) sanctuary entrance, (b) Maattu muni kovil - a temple visited by local cowherds, (c) Savukku plot or Casuarina plantation, (d) S-Bend road, and (e) the old light house. Rapid survey was conducted within the sanctuary for almost a month and a total of about 120 hours were spent exclusively for observing foraging and resting habits of Blackbucks in the PCWS. During the study period, field binoculars were used to observe the grazing activities. The segments were explored to interpret the foraging pattern of Blackbucks and to make a list of plants available in the sanctuary, which was further used to understand the components of the vegetation. Most of the plant species were identified on the site and undesignated plant specimens especially the grasses were taken to the laboratory for identification. All the identified plant species were classified based on their 

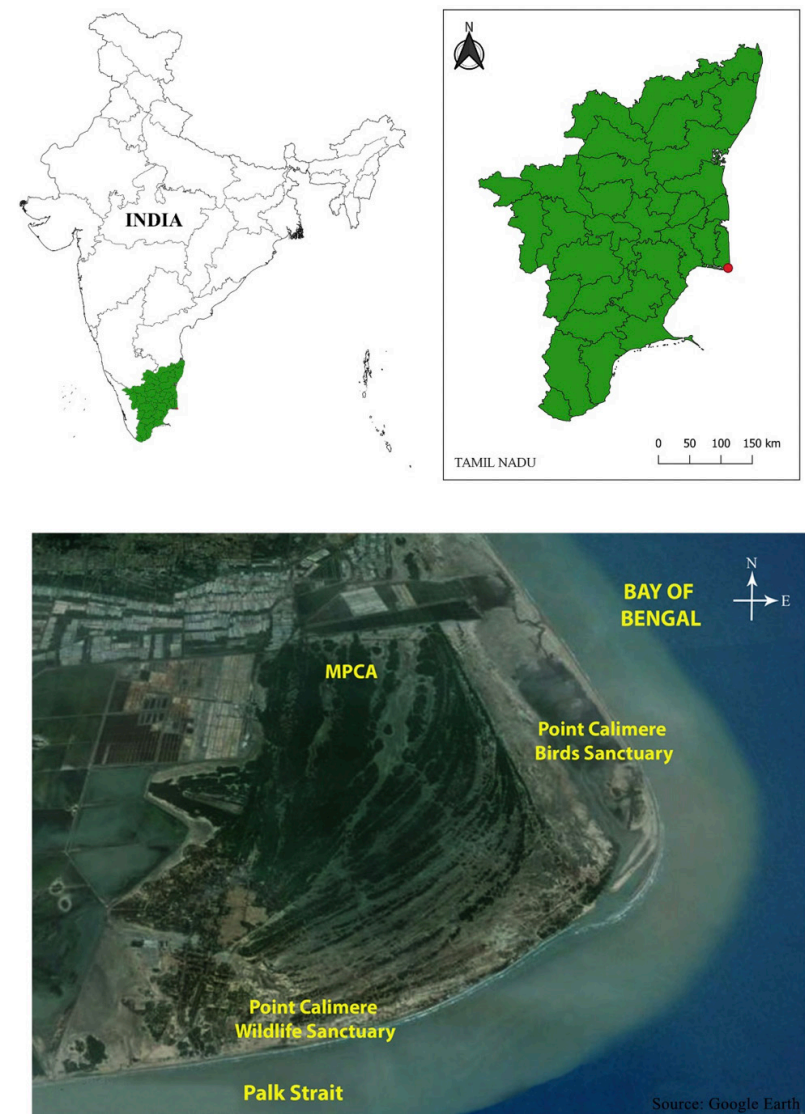

Figure 1. Study area

habitats. The botanical names of the plant species were updated using online databases such as POWO (2020), The Plant list (2013) and The International Plant Name Index (IPNI 2018). Specimens were also photographed and kept for reference.

\section{RESULTS}

A total of 111 plant species that included 50 herbs (12 grasses, five sedges and four creepers), 16 climbers/ lianas, 30 shrubs \& subshrubs, and 15 trees belonging to 39 plant families were recorded in this study (Figure 2). Of the plant families recorded Fabaceae, Poaceae, Amaranthaceae, Lamiaceae, Cyperaceae, Rubiaceae, Convolvulaceae, and Asteraceae were the most speciesrich families having four or more species each (Figure 3 ). The habitats of different plant species observed were divided into five major types, namely, (a) Inundated plains-areas getting seasonally flooded, dominated by Chloris virgata Sw., Cynodon barberi Rang. \& Tadul., C. dactylon (L.) Pers., Perotis indica (L.) Kuntze, Fimbristylis acuminata Vahl, F. argentea (Rottb.) Vahl,
Epaltes pygmaea DC., and Platostoma menthoides (L.) A.J.Paton; (b) Low mounds-an elevated land c. a meter high, dominated by Eragrostis viscosa (Retz.) Trin.; (c) High mounds - an elevated land c. 1.5-2 m high, having Cyanthillium cinereum (L.) H.Rob., (d) Sand dunessmall hills of loose sand, with species such as Calotropis gigantea (L.) W.T.Aiton. and Ipomoea pes-caprae (L.) R.Br.; and (e) Mangrove-tropical coastal vegetation comprising of salt tolerant species such as Avicennia marina (Forssk.) Vierh. and Excoecaria agallocha L. The term 'mound' used here is to distinguish elevated patches of land from the rest of the study area. Many plant species (except mangroves) were not rigidly habitat specific and were observed occurring in different habitats. A checklist of plants with their local Tamil names and habitats within the sanctuary was also prepared (cf. Appendix I).

Visual observations from a distance followed by instantaneous site visits in the field showed that the Blackbucks preferred to graze on selected grasses such as Aeluropus lagopoides (L.) Thwaites, Cynodon barberi Rang. \& Tadul., C. dactylon (L.) Pers., Chloris virgata Sw.,

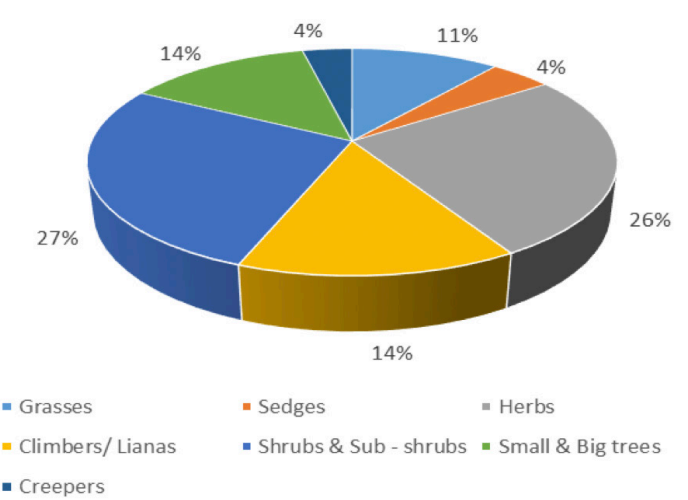

Figure 2. Habit types observed at Point Calimere Wildlife Sanctuary.

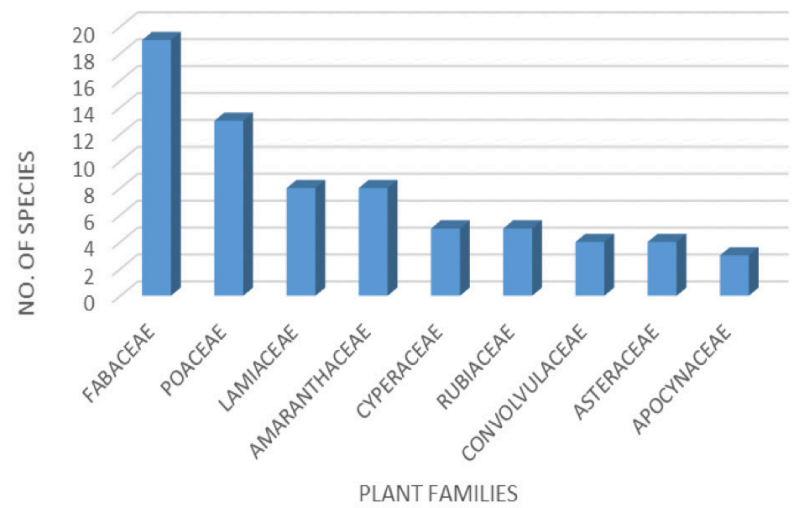

Figure 3. Dominant Plant families. 
Table 1. Suggested fodder species for introduction in Point Calimere Wildlife Sanctuary.

\begin{tabular}{|c|l|l|}
\hline 1. & Grass species for Blackbucks & $\begin{array}{l}\text { Cynodon radiatus Roth, Blue panic grass Panicum coloratum L., Panicum curviflorum Hornem., Torpedo grass } \\
\text { Panicum repens L., Setaria flavida (Retz.) Veldkamp }\end{array}$ \\
\hline 2. & $\begin{array}{l}\text { Grasses to be introduced in saline } \\
\text { areas }\end{array}$ & $\begin{array}{l}\text { Sprangle top Leptochloa obtusiflora Hochst., Sporobolus maderaspatanus Bor, Coastal rat tail grass Sporobolus } \\
\text { virginicus (L.) Kunth }\end{array}$ \\
\hline 3. & $\begin{array}{l}\text { Grasses to be introduced in sandy } \\
\text { areas }\end{array}$ & $\begin{array}{l}\text { Daabh Desmostachya bipinnata (L.) Stapf, Dimeria avenacea (Retz.) C.E.C.Fisch., Manisuris myurus L., Indian comet } \\
\text { grass Perotis indica (L.) Kuntze, Trachys muricata (L.) Pers. ex Trin }\end{array}$ \\
\hline 4. & $\begin{array}{l}\text { Tree species to be introduced } \\
\text { within the sanctuary }\end{array}$ & $\begin{array}{l}\text { Babul Vachellia nilotica (L.) P.J.H.Hurter\&Mabb., Reonja Vachellia leucophloea (Roxb.) Maslin, Seigler \& Ebinger, Bidi } \\
\text { leaf treeBauhinia racemosa Lam., Flame of the forest Butea monosperma (Lam.) Kuntze, Siris tree Albizia lebbeck } \\
\text { (L.) Benth., Krishna Siris Albizia amara (Roxb.) B.Boivin, Black Siris Albizia odoratissima (L.f.) Benth., Indian Coral } \\
\text { tree Erythrina variegata L. }\end{array}$ \\
\hline
\end{tabular}

a sedge Fimbristylis acuminata Vahl during the day time and they were seen browsing on the leaves and pods of Prosopis juliflora (Sw.) DC. in the evenings usually before sunset. They preferred grazing in open areas and around mounds. They were usually observed grazing in herds and rarely in solitude.

\section{DISCUSSION}

Conservation of the whole habitat of blackbucks in the sanctuary initially resulted in multiplication of their numbers but that was impeded due to the increase in the number of feral horses and stray cattle over the years. Entry of feral horses and stray cattle into the sanctuary poses two main problems: (a) competition for food and water and (b) spread of invasive alien plant species. Pods of Prosopis juliflora (Sw.) DC., one of the most aggressive invasive alien species is preferred by these cattle and the seeds were dispersed through their faeces into the sanctuary area, leading to the spread and increase in its population. By trampling the vegetation, altering the soil texture and overgrazing, these animals have a penetrating effect on the ecosystem. Feral horses build up to high numbers during good years, and many starve during drought (Wilson et al. 1992). Quality and nutritional value of plants available for grazing influences the diet and habitat relationship in large herbivores (Ahrestani et al. 2012). The distribution pattern of plant species and their dominance in an area plays an important role in their preference by these herbivores (Chamaille-Jammes \& Bond 2010). Blackbucks, cattle from nearby villages, and feral horses, all compete for the same forage stock and there are not many differences between their foraging habits.

To control the competition faced by Blackbucks in PCWS by feral horses and stray cattle a few steps may be implemented.

1. Native fodder species can be introduced into the sanctuary on an experimental basis to provide more fodder to herbivores and to enhance local biodiversity (Dayanandan 1994). A few fodder species including grasses and leguminous trees have been listed for this purpose. (Table 1).

2. Stray cattle from the nearby villages can be stopped by fencing at strategic places where they are most probable to enter inside, and awareness programs can be conducted to educate the nearby villagers about the ecological and cultural significance of Blackbucks and the ill-effects of stray cattle grazing in the sanctuary premises. The population of feral horses can be controlled by methods such as relocation and sterilization (Khan et al. 2019).

\section{CONCLUSION}

This study has employed a very simple direct observational methodology for collection of data sets from PCWS. In spite of the seasonal limitations experienced, it provides a base for possible furthering of full-fledged ecological, floristic, and conservation studies in the area. Field surveys in different seasons need to be undertaken for a holistic understanding of the ecology of Blackbuck in Point Calimere with emphasis on the fodder species, especially the grasses. This study is expected to help prepare policies for plantation of fodder species in the sanctuary, and help in conservation of Blackbuck population with their long-term survival. The suggested mitigation measures are expected to help in controlling the spread of invasive alien plant species too, thereby, enriching the local flora. 

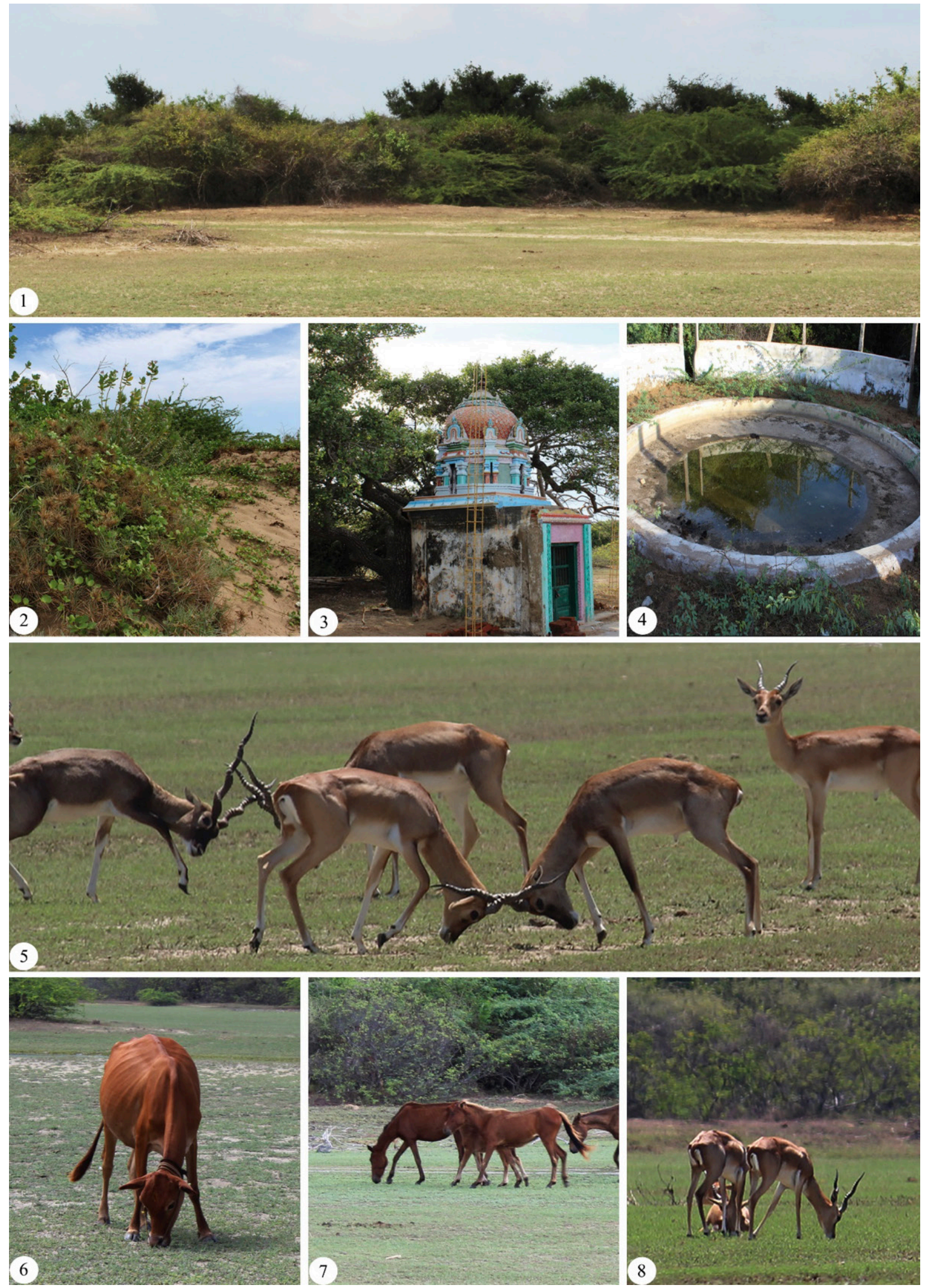

Image 1. 1-A view of the tropical dry evergreen forest (TDEF) in Blackbuck habitat of Point Calimere Wildlife Sanctuary | 2-Vegetation on sand dunes | 3-The sanctuary entrance and beginning of study segment at Maattu-muni kovil | 4-Constructed water pool by used spotted deers and feral horses during dry seasons | 5-Blackbucks in the Sanctuary | 6-Local cattle grazing in the sanctuary, a competition for Blackbucks for fodder and water | 7-Feral horses spotted in the sanctuary | 8-Blackbucks grazing in slightly inundated plains. (๑) Ashutosh Kumar Upadhyay 

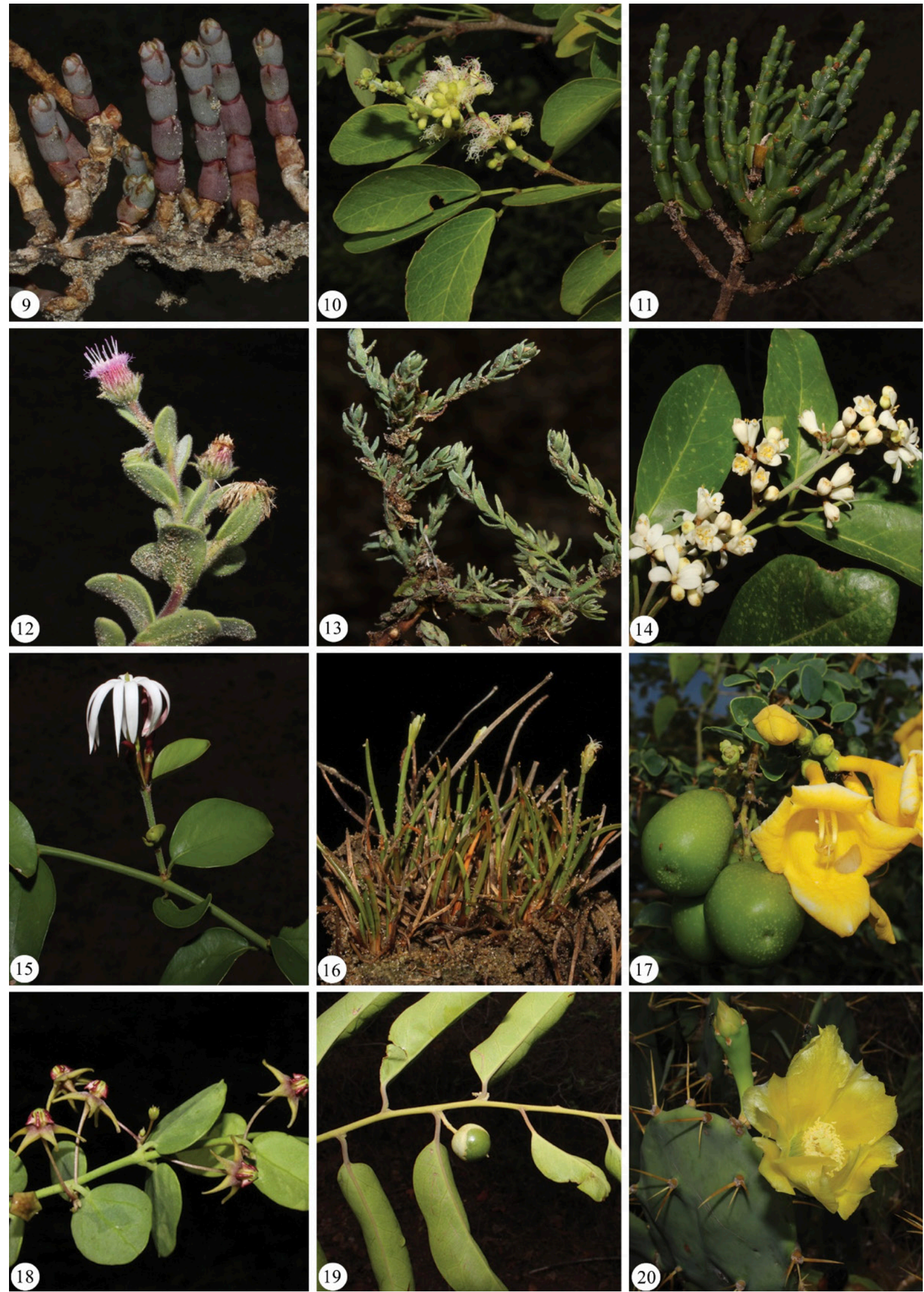

Image 2. Flora of Point Calimere Wildlife Sanctuary: 9-Salicornia brachiata Roxb. | 10-Pithecellobium dulce (Roxb.) Benth. | 11-Tecticornia indica (Willd.) K.A. Sheph. \& Paul | 12-Epaltes divaricata Cass. | 13-Cressa cretica L. | 14-Glycosmis mauritiana (Lam.) Tanaka | 15Jasminum angustifolium (L.) Willd. | 16-Fimbristylis acuminata Vahl | 17-Gmelina asiatica L. | 18-Pentatropis capensis (L.f.) Bullock | 19-Olax scandens Roxb. | 20-Opuntia dillenii (Ker Gawl.) Haw. @ A Ashutosh Kumar Upadhyay 

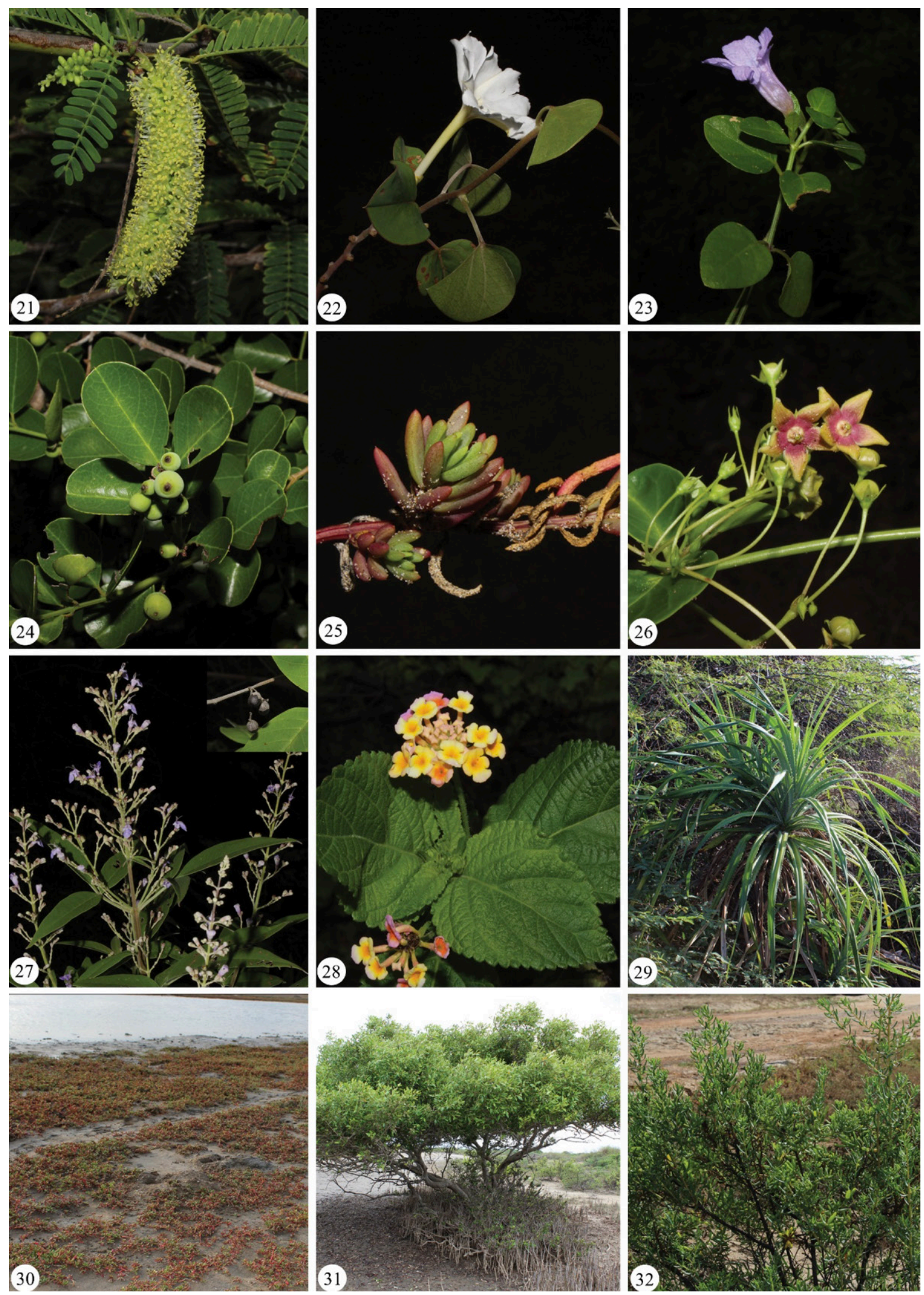

Image 3. Flora of Point Calimere Wildlife Sanctuary: 21-Prosopis juliflora (Sw.) DC. | 22-Rivea hypocrateriformis (Desr.) Choisy | 23-Ruellia patula Jacq. | 24-Scutia myrtina (Burm.f.) Kurz | 25-Suaeda maritima (L.) Dumort. | 26-Vincetoxicum indicum (Burm.f.) Mabb. | 27-Vitex negundo L. (inset- fruits) | 28-Lantana camara L. | 29-Pandanus odorifer (Forssk.) Kuntze | 30-Sesuvium portulacastrum (L.) L. | 31Avicennia marina (Forssk.) Vierh. | 32-Suaeda monoica Forssk. ex J.F. Gmel. @ Ashutosh Kumar Upadhyay 


\section{REFERENCES}

Ahrestani, F.S., I.M.A. Heitkonig \& H.H.T Prins (2012). Diet and habitatniche relationships within an assemblage of large herbivores in a seasonal tropical forest. Journal of Tropical Ecologyl 28: 385-394.

Ali, R. (2005). Field studies for the conservation and management of point Calimere Complex. Foundation for Ecological Research, Advocacy and Learning. A Report for the Tamil Nadu Forest Department, $40 \mathrm{pp}$.

Altman, J. (1974). Observational study of behaviour: Sampling methods. Behaviour 49: 227-267.

Baruah, A.D. (2005). Point Calimere Wildlife \& Bird Sanctuary-A Ramsar Site. Tamil Nadu Forest Department, $180 \mathrm{pp.}$

Chamaille-Jammes, S. \& W.J. Bond (2010). Will global change improve grazing quality of grasslands? A call for a deeper understanding of the effects of shifts from C-4 to C-3 grasses for large herbivores. Oikos 119: 1857-1861.

Champion, H.G. \& S.K. Seth (1968). A Revised Survey of the Forest Types of India. Manager of Publications, Delhi, xxvii+404 pp.

Dayanandan, P. (1994). Maximization of the Value of Native fodder grasses and grazing lands. Society for Social Forestry Research and Development, Tamil Nadu, $52 \mathrm{pp}$.

Hundal, S.S. (2004). Wildlife Conservation Strategies and Management in India: An Overview. Proceedings Species at Risk 2004 Pathways to Recovery Conference, Victoria B.C., Canada, 2: 2-6.

IPNI (2018). International Plant Names Index. Published on the Internet (http://www.ipni.org), The Royal Botanic Gardens, Kew, Harvard University Herbaria \& Libraries and Australian National
Botanic Gardens. [Retrieved 03 June 2018].

Khan, K.A., S. Savan, B. Singh, R. De, V.B. Mathur, A. Rajvashi, B. Habib, S.P. Goyal \& A.K. Bhardwaj (2019). Abohar-Sito GunnoDabwali road (NH-354E) section passing through Abohar Wildlife Sanctuary, Punjab, India. Technical Report. Wildlife Institute of India, Dehradun, 57 pp.

Meher-Homji, V.M. (1974). On the origin of the tropical dry evergreen forest of south India. International Journal of Ecology and Environmental Sciences 1: 19-39.

Parthasarthy, N., P. Vivek \& K. Anil (2015). Liana diversity and their Ecosystem Services in Tropical Dry Evergreen Forest on the Coromandel Coast of India, pp. 161-178. In: Parthasarthy, N. (ed.). Biodiversity of Lianas, Sustainable Development and Biodiversity. Vol.5. https://doi.org/10.1007/978-3-319-14592-1_10.

POWO (2020). Plants of the World Online. Facilitated by the Royal Botanic Gardens, Kew. http://www.plantsoftheworldonline.org/. Retrieved 21 February 2020.

The Plant List (2013). Version 1.1. Published on the Internet. Accessed 3 June 2015; http://www.theplantlist.org/

The Wildlife Protection Act (1972). http://nbaindia.org/uploaded/ Biodiversityindia/Legal/15.\%20Wildlife\%20(Protection)\%20 Act,\%201972.pdf

USDA Agricultural Research Service (2015). Germplasm Resources Information Network (GRIN). Ag Data Commons. https://doi. org/10.15482/USDA.ADC/1212393. Accessed 2018-03-03.

Wilson, G., A. McNee \& P. Platts (1992). Wild animal resources: their use by aboriginal communities. Australian Government Publishing Service, Canberra, $x+122 \mathrm{pp}$.

Appendix I. List of plants observed at Point Calimere Wildlife Sanctuary

\begin{tabular}{|c|c|c|c|}
\hline Sno & Binomial \& Common names & Family & Habitat \\
\hline \multicolumn{4}{|c|}{ GRASSES } \\
\hline 1 & Aeluropus lagopoides (L.) Thwaites & Poaceae & Inundated plains \\
\hline 2 & $\begin{array}{l}\text { Stapfochloa elata (Desv.) P.M.Peterson } \\
\text { Tamil name: Kodai pullu, Sevarug pullu }\end{array}$ & Poaceae & Inundated plains \\
\hline 3 & Chloris virgata Sw. & Poaceae & Inundated plains \\
\hline 4 & Cynodon barberi Rang. \& Tadul. & Poaceae & Inundated plains \\
\hline 5 & $\begin{array}{l}\text { Cynodon dactylon (L.) Pers. } \\
\text { Tamil name: Arugam pullu }\end{array}$ & Poaceae & Inundated plains \\
\hline 6 & Dactyloctenium aegyptium (L.) Willd. & Poaceae & Inundated plains \\
\hline 7 & Eragrostis sp. & Poaceae & Inundated plains with sparse trees \\
\hline 8 & $\begin{array}{l}\text { Eragrostis tenella (L.) P.Beauv. ex Roem. \& Schult } \\
\text { Tamil name: Poom Pullu }\end{array}$ & Poaceae & Low mounds \\
\hline 9 & Eragrostis viscosa (Retz.) Trin. & Poaceae & Low mounds \\
\hline 10 & Panicum sp. & Poaceae & High mounds and Inundated plains \\
\hline 11 & $\begin{array}{l}\text { Perotis indica (L.) Kuntze } \\
\text { Tamil name: Narival, Kudiraival pullu, Thopparai pullu }\end{array}$ & Poaceae & Inundated plains \\
\hline 12 & $\begin{array}{l}\text { Spinifex littoreus (Burm.f.) Merr. } \\
\text { Tamil name: Elikunjai pullu, Ravanan meesai }\end{array}$ & Poaceae & Sand dunes \\
\hline \multicolumn{4}{|c|}{ SEDGES } \\
\hline 1 & Cyperus dubius Rottb. & Cyperaceae & Inundated plains \\
\hline 2 & Fimbristylis acuminata Vahl & Cyperaceae & Inundated plains \\
\hline 3 & Fimbristylis argentea (Rottb.) Vahl & Cyperaceae & Inundated plains \\
\hline 4 & Fimbristylis falcata (Vahl) Kunth & Cyperaceae & Inundated plains \\
\hline 5 & Fimbristylis $s p$ & Cyperaceae & Inundated plains \\
\hline \multicolumn{4}{|c|}{ HERBS } \\
\hline 1 & $\begin{array}{l}\text { Achyranthes aspera } \mathrm{L} \text {. } \\
\text { Tamil name: Nayurivi }\end{array}$ & Amaranthaceae & Inundated plains with sparse trees \\
\hline
\end{tabular}




\begin{tabular}{|c|c|c|c|}
\hline Sno & Binomial \& Common names & Family & Habitat \\
\hline 2 & $\begin{array}{l}\text { Ouret lanata (L.) Kuntze } \\
\text { Tamil name: Peelai, Sirupeelai }\end{array}$ & Amaranthaceae & Inundated plains with sparse trees \\
\hline 3 & $\begin{array}{l}\text { Salicornia brachiata Roxb. } \\
\text { Tamil name: Kolliam, Pavalappundu }\end{array}$ & Amaranthaceae & Halophytic \\
\hline 4 & Asystasia gangetica (L.) T. Anderson & Acanthaceae & $\begin{array}{l}\text { Inundated plains with sparse trees and } \\
\text { low mounds }\end{array}$ \\
\hline 5 & $\begin{array}{l}\text { Boerhavia diffusa } \mathrm{L} \text {. } \\
\text { Tamil name: Mookarattai }\end{array}$ & Nyctaginaceae & Inundated plains with sparse trees \\
\hline 6 & $\begin{array}{l}\text { Cressa cretica } \mathrm{L} \text {. } \\
\text { Tamil name: Vuppu marikkozhundhu }\end{array}$ & Convolvulaceae & Inundated plains \\
\hline 7 & $\begin{array}{l}\text { Croton bonplandianus Baill. } \\
\text { Tamil name: Rail poondu }\end{array}$ & Euphorbiaceae & $\begin{array}{l}\text { Inundated plains with sparse trees and } \\
\text { low mounds }\end{array}$ \\
\hline 8 & $\begin{array}{l}\text { Cyanthillium cinereum (L.) H. Rob. } \\
\text { Tamil name: Mookutthipoondu, Sahadevi }\end{array}$ & Asteraceae & Low mounds with sparse trees \\
\hline 9 & Epaltes divaricata (L.) Cass. & Asteraceae & Inundated plains \\
\hline 10 & Epaltes $s p$. & Asteraceae & Inundated plains \\
\hline 11 & Geniosporum sp. & Lamiaceae & Inundated plains \\
\hline 12 & $\begin{array}{l}\text { Tecticornia indica (Willd.) K.A.Sheph. \& Paul G.Wilson } \\
\text { Tamil name: Pavazhappundu, Sitrumari }\end{array}$ & Amaranthaceae & Halophytic \\
\hline 13 & Leucas diffusa Benth. & Lamiaceae & Inundated plains with sparse trees \\
\hline 14 & $\begin{array}{l}\text { Ocimum americanum } \mathrm{L} . \\
\text { Tamil name: Ganjaankorai, Nai thulasi }\end{array}$ & Lamiaceae & Inundated plains with sparse trees \\
\hline 15 & $\begin{array}{l}\text { Ocimum tenuiflorum } \mathrm{L} \text {. } \\
\text { Tamil name: Thulasi, Rama thulasi }\end{array}$ & Lamiaceae & Inundated plains with sparse trees \\
\hline 16 & Oldenlandia herbacea (L.) Roxb. & Rubiaceae & Inundated plains with sparse trees \\
\hline 17 & Oldenlandia umbellata $\mathrm{L}$. & Rubiaceae & Inundated plains with sparse trees \\
\hline 18 & $\begin{array}{l}\text { Vicoa indica (L.) DC. } \\
\text { Tamil name: Jimikipoo, Mookutthipoondu }\end{array}$ & Asteraceae & Inundated plains with sparse trees \\
\hline 19 & $\begin{array}{l}\text { Platostoma menthoides (L.) A.J.Paton } \\
\text { Tamil name: Ganjaankorai }\end{array}$ & Lamiaceae & Inundated plains \\
\hline 20 & Ruellia patula Jacq. & Acanthaceae & Inundated plains with sparse trees \\
\hline 21 & Synostemon bacciformis (L.) G.L.Webster & Phyllanthaceae & $\begin{array}{l}\text { Inundated plains with sparse trees and } \\
\text { low mounds }\end{array}$ \\
\hline 22 & Sesuvium portulacastrum (L.) L. & Aizoaceae & Halophytic \\
\hline 23 & $\begin{array}{l}\text { Spermacoce hispida L. } \\
\text { Tamil name: Nathaichoori }\end{array}$ & Rubiaceae & Sand dunes \\
\hline 24 & $\begin{array}{l}\text { Suaeda maritima (L.) Dumort. } \\
\text { Tamil name: Nari vumari, Uppukkeerai }\end{array}$ & Amaranthaceae & Halophytic \\
\hline 25 & Suaeda vermiculata Forssk.ex J.F. Gmel. & Amaranthaceae & Halophytic \\
\hline 26 & $\begin{array}{l}\text { Tephrosia maxima (L.) Pers. } \\
\text { Tamil name: Kollukaai vaelai, Periya kozhinji }\end{array}$ & Fabaceae & Inundated plains with sparse trees \\
\hline 27 & $\begin{array}{l}\text { Tephrosia purpurea (L.) Pers. } \\
\text { Tamil name: Kozhinji, Kollukaai vaelai }\end{array}$ & Leguminosae & Inundated plains with sparse trees \\
\hline 28 & Vahlia dichotoma (Murray) Kuntze & Vahliaceae & Inundated plains \\
\hline 29 & $\begin{array}{l}\text { Vigna trilobata (L.) Verdc. } \\
\text { Tamil name: Pani payaru }\end{array}$ & Fabaceae & Inundated plains with sparse trees \\
\hline \multicolumn{4}{|c|}{ CLIMBER / LIANA } \\
\hline 1 & $\begin{array}{l}\text { Abrus precatorius } \mathrm{L} \text {. } \\
\text { Tamil name: Kundumani }\end{array}$ & Fabaceae & Inundated plains with sparse trees \\
\hline 2 & $\begin{array}{l}\text { Asparagus racemosus Willd. } \\
\text { Tamil name: Thaneer vitaan kizhangu, Sadhavaeri }\end{array}$ & Asparagaceae & Inundated plains with sparse trees \\
\hline 3 & Capparis brevispina DC. & Capparaceae & High mound with sparse trees \\
\hline 4 & $\begin{array}{l}\text { Capparis zeylanica } \mathrm{L} . \\
\text { Tamil name: Athondai }\end{array}$ & Capparaceae & Inundated plains with sparse trees \\
\hline 5 & $\begin{array}{l}\text { Cissus quadrangularis L. } \\
\text { Tamil name: Pirandai }\end{array}$ & Vitaceae & Inundated plains and low mounds \\
\hline 6 & $\begin{array}{l}\text { Cissus vitiginea } \mathrm{L} \text {. } \\
\text { Tamil name: Chembirandai, Mudai naari }\end{array}$ & Vitaceae & Inundated plains with sparse trees \\
\hline 7 & $\begin{array}{l}\text { Coccinia grandis (L.) Voigt } \\
\text { Tamil name: Kovai }\end{array}$ & Cucurbitaceae & Inundated plains with sparse trees \\
\hline
\end{tabular}




\begin{tabular}{|c|c|c|c|}
\hline Sno & Binomial \& Common names & Family & Habitat \\
\hline 8 & $\begin{array}{l}\text { Gmelina asiatica } \mathrm{L} . \\
\text { Tamil name: Nilakkumizh, Mulkumizh }\end{array}$ & Lamiaceae & Inundated plains \\
\hline 9 & $\begin{array}{l}\text { Jasminum angustifolium (L.) Willd. } \\
\text { Tamil name: Kaattu malli, Paambu kala }\end{array}$ & Oleaceae & Inundated plains with sparse trees \\
\hline 10 & $\begin{array}{l}\text { Jasminum cuspidatum Rottler } \\
\text { Tamil name: Oosi malli }\end{array}$ & Oleaceae & Inundated plains with sparse trees \\
\hline 11 & $\begin{array}{l}\text { Olax scandens Roxb. } \\
\text { Tamil name: Kadal azhinji, Malli vaeppam }\end{array}$ & Olacaceae & Low mound with sparse trees \\
\hline 12 & $\begin{array}{l}\text { Pentatropis capensis (L. f.) Bullock } \\
\text { Tamil name: Uppili, Uppilankodi }\end{array}$ & Apocynaceae & Halophytic \\
\hline 13 & $\begin{array}{l}\text { Rivea hypocrateriformis (Desr.)Choisy } \\
\text { Tamil name: Boodhikeerai }\end{array}$ & Convolvulaceae & Low mound with sparse trees \\
\hline 14 & $\begin{array}{l}\text { Scutia myrtina (Burm. f.) Kurz } \\
\text { Tamil name: Indu, Kokku mullu }\end{array}$ & Rhamnaceae & Inundated plains \\
\hline 15 & $\begin{array}{l}\text { Solanum trilobatum } \mathrm{L} . \\
\text { Tamil name: Thoodhuvalai }\end{array}$ & Solanaceae & Inundated plains with sparse trees \\
\hline 16 & $\begin{array}{l}\text { Vincetoxicum indicum (Burm.f.) Mabb. } \\
\text { Tamil name: Naippalai, Nanjaruppaan }\end{array}$ & Apocynaceae & Inundated plains with sparse trees \\
\hline \multicolumn{4}{|c|}{ SHRUBS \& SUB-SHRUBS } \\
\hline 1 & $\begin{array}{l}\text { Azima tetracantha Lam. } \\
\text { Tamil name: Pee changam, Mulsangam }\end{array}$ & Salvadoraceae & Inundated plains \\
\hline 2 & Acacia sp. & Fabaceae & Inundated plains \\
\hline 3 & $\begin{array}{l}\text { Guilandina bonduc L. } \\
\text { Tamil name: Kazharchikaai, Gajjakkaai }\end{array}$ & Fabaceae & Inundated plains and sand dunes \\
\hline 4 & $\begin{array}{l}\text { Calotropis gigantea (L.) W.T.Aiton } \\
\text { Tamil name: Erukku, Arkkam }\end{array}$ & Apocynaceae & Sand dunes \\
\hline 5 & Canthium parviflorum Roxb. & Rubiaceae & Inundated plains with sparse trees \\
\hline 6 & $\begin{array}{l}\text { Catunaregam spinosa (Thunb.) Tirveng. } \\
\text { Tamil name: Kaalagam, Madukaarai }\end{array}$ & Rubiaceae & Inundated plains with sparse trees \\
\hline 7 & Chamaerops humilis L. & Arecaeae & Inundated plains with sparse trees \\
\hline 8 & $\begin{array}{l}\text { Crotalaria laburnifolia } \mathrm{L} . \\
\text { Tamil name: Kilukiluppai, Narimiratti }\end{array}$ & Fabaceae & Inundated plains with sparse trees \\
\hline 9 & Crotalaria pallida Aiton & Fabaceae & Inundated plains with sparse trees \\
\hline 10 & $\begin{array}{l}\text { Dichrostachys cinerea (L.) White \& Arn. } \\
\text { Tamil name: Vidathalam thazhai }\end{array}$ & Fabaceae & Inundated plains \\
\hline 11 & $\begin{array}{l}\text { Diospyros ferrea (Willd.) Bakh. } \\
\text { Tamil name: Irumbuli }\end{array}$ & Ebenaceae & Inundated plains with sparse trees \\
\hline 12 & Ehretia microphylla Lam. & Boraginaceae & Inundated plains \\
\hline 13 & $\begin{array}{l}\text { Flueggea leucopyrus Willd. } \\
\text { Tamil name: Pulanji }\end{array}$ & Phyllanthaceae & Inundated plains \\
\hline 14 & $\begin{array}{l}\text { Glycosmis mauritiana (Lam.) Tanaka } \\
\text { Tamil name: Konji }\end{array}$ & Rutaceae & Inundated plains with sparse trees \\
\hline 15 & Grewia carpinifolia Juss. & Malvaceae & Inundated plains with sparse trees \\
\hline 16 & $\begin{array}{l}\text { Gymnosporia emarginata (Willd.) Thwaites } \\
\text { Tamil name: Kattanji }\end{array}$ & Celastraceae & Inundated plains \\
\hline 17 & $\begin{array}{l}\text { Hygrophila auriculata (Schumach.) Heine } \\
\text { Tamil name: Neermulli }\end{array}$ & Acanthaceae & Inundated plains \\
\hline 18 & $\begin{array}{l}\text { Lantana camara } \mathrm{L} . \\
\text { Tamil name: Unnichedi, Jimiki malli }\end{array}$ & Verbenaceae & Inundated plains \\
\hline 19 & $\begin{array}{l}\text { Opuntia dillenii (Ker Gawl.) Haw. } \\
\text { Tamil name: Chappathikkalli }\end{array}$ & Cactaceae & Inundated plains and low mounds \\
\hline 20 & $\begin{array}{l}\text { Pandanus odorifer (Forssk.) Kuntze } \\
\text { Tamil name: Thazhai, Kaidha }\end{array}$ & Pandanaceae & Inundated plains \\
\hline 21 & $\begin{array}{l}\text { Prosopis juliflora (Sw.) DC. } \\
\text { Tamil name: Velikkaathaan, Seemai mullu }\end{array}$ & Fabaceae & Inundated plains \\
\hline 22 & Psilotrichum elliotii Baker & Amaranthaceae & Inundated plains and low mounds \\
\hline 23 & $\begin{array}{l}\text { Senna auriculata (L.) Roxb. } \\
\text { Tamil name: Avaram, Avaarai }\end{array}$ & Fabaceae & Inundated plains and low mounds \\
\hline 24 & $\begin{array}{l}\text { Senna occidentalis (L.) Link } \\
\text { Tamil name: Peiyavarai, Thagarai }\end{array}$ & Fabaceae & Inundated plains and low mounds \\
\hline 25 & Senna timoriensis (D.C.) H.S. Irwin \& Barneby & Fabaceae & Inundated plains \\
\hline
\end{tabular}




\begin{tabular}{|c|c|c|c|}
\hline Sno & Binomial \& Common names & Family & Habitat \\
\hline 26 & $\begin{array}{l}\text { Suaeda monoica Forssk. ex J.F. Gmel. } \\
\text { Tamil name: Karuvumari, Umarinandi }\end{array}$ & Amaranthaceae & Halophytic \\
\hline 27 & $\begin{array}{l}\text { Vitex negundo L. } \\
\text { Tamil name: Nochi, Vennochi }\end{array}$ & Lamiaceae & High mound with sparse trees \\
\hline 28 & $\begin{array}{l}\text { Volkameria inermis L. } \\
\text { Tamil name: Pinchil, Pinarichanganguppu }\end{array}$ & Lamiaceae & Inundated plains \\
\hline 29 & $\begin{array}{l}\text { Ziziphus jujuba Mill. } \\
\text { Tamil name: Illandhai }\end{array}$ & Rhamnaceae & Inundated plains \\
\hline 30 & $\begin{array}{l}\text { Ziziphus oenopolia (L.) Mill. } \\
\text { Tamil name: Soorai pazham, Soorai mullu }\end{array}$ & Rhamnaceae & Inundated plains with sparse trees \\
\hline \multicolumn{4}{|c|}{ SMALL AND BIG TREES } \\
\hline 1 & $\begin{array}{l}\text { Albizia lebbeck (L.) Benth. } \\
\text { Tamil name: Vaagai }\end{array}$ & Fabaceae & Inundated plains with sparse trees \\
\hline 2 & $\begin{array}{l}\text { Avicennia marina (Forssk.) Vierh. } \\
\text { Tamil name: Venkandal, Vellaikkandal }\end{array}$ & Avicenniaceae & Mangrove \\
\hline 3 & $\begin{array}{l}\text { Azadirachta indica A. Juss. } \\
\text { Tamil name: Vaembu, Vaeppam }\end{array}$ & Meliaceae & Inundated plains \\
\hline 4 & $\begin{array}{l}\text { Cassia fistula L. } \\
\text { Tamil name: Kondrai, Sarakkondrai }\end{array}$ & Fabaceae & Inundated plains \\
\hline 5 & $\begin{array}{l}\text { Casuarina equisetifolia L. } \\
\text { Tamil name: Savukku }\end{array}$ & Casuarinaceae & Inundated plains \\
\hline 6 & $\begin{array}{l}\text { Excoecaria agallocha } \mathrm{L} . \\
\text { Tamil name: Thillai }\end{array}$ & Euphorbiaceae & Mangrove \\
\hline 7 & $\begin{array}{l}\text { Ficus benghalensis } \mathrm{L} \text {. } \\
\text { Tamil name: Aal, Ichi }\end{array}$ & Moraceae & Sand dunes \\
\hline 8 & $\begin{array}{l}\text { Lannea coromandelica (Houtt.) Merr. } \\
\text { Tamil name: Odhiya maram, Odhi }\end{array}$ & Anacardiaceae & Inundated plains \\
\hline 9 & $\begin{array}{l}\text { Manilkara hexandra (Roxb.) Dubard } \\
\text { Tamil name: Kannupalai, Paala maram }\end{array}$ & Sapotaceae & Inundated plains with sparse trees \\
\hline 10 & $\begin{array}{l}\text { Peltophorum pterocarpum (DC.) Backer ex K. Heyne } \\
\text { Tamil name: Iyalvaagai, Perugondrai }\end{array}$ & Fabaceae & Inundated plains with sparse trees \\
\hline 11 & $\begin{array}{l}\text { Pithecellobium dulce (Roxb.) Benth. } \\
\text { Tamil name: Kodukkaai puli }\end{array}$ & Fabaceae & Inundated plains and high mounds \\
\hline 12 & $\begin{array}{l}\text { Pongamia pinnata (L.) Pierre } \\
\text { Tamil name: Punga maram }\end{array}$ & Fabaceae & Inundated plains \\
\hline 13 & $\begin{array}{l}\text { Premna serratifolia L. } \\
\text { Tamil name: Munnai }\end{array}$ & Lamiaceae & Inundated plains with sparse trees \\
\hline 14 & $\begin{array}{l}\text { Salvadora persica } \mathrm{L} \text {. } \\
\text { Tamil name: Chitthu vila, Kalarva }\end{array}$ & Salvadoraceae & Inundated plains \\
\hline 15 & $\begin{array}{l}\text { Thespesia populnea (L.) Sol. ex Correa } \\
\text { Tamil name: Poovarasu }\end{array}$ & Malvaceae & Inundated plains \\
\hline \multicolumn{4}{|c|}{ CREEPERS } \\
\hline 1 & $\begin{array}{l}\text { Grona triflora (L.) H.Ohashi \& K.Ohashi } \\
\text { Tamil name: Sirupulladi }\end{array}$ & Fabaceae & Inundated plains \\
\hline 2 & $\begin{array}{l}\text { Euphorbia thymifolia L. } \\
\text { Tamil name: Sittrapaladai }\end{array}$ & Euphorbiaceae & Low level shady moist area \\
\hline 3 & $\begin{array}{l}\text { Evolvulus alsinoides (L.) L. } \\
\text { Tamil name: Vishnukarandi }\end{array}$ & Convolvulaceae & Inundated plains with sparse trees \\
\hline 4 & $\begin{array}{l}\text { Ipomoea pes-caprae (L.) R. Br. } \\
\text { Tamil name: Attukkal, Kudhirai kulambu }\end{array}$ & Convolvulaceae & Sand dunes \\
\hline
\end{tabular}



Dr. John Noyes, Natural History Museum, London, UK

Dr. Albert G. Orr, Griffith University, Nathan, Australia

Dr. Sameer Padhye, Katholieke Universiteit Leuven, Belgium

Dr. Nancy van der Poorten, Toronto, Canada

Dr. Kareen Schnabel, NIWA, Wellington, New Zealand

Dr. R.M. Sharma, (Retd.) Scientist, Zoological Survey of India, Pune, India

Dr. Manju Siliwal, WILD, Coimbatore, Tamil Nadu, India

Dr. G.P. Sinha, Botanical Survey of India, Allahabad, India

Dr. K.A. Subramanian, Zoological Survey of India, New Alipore, Kolkata, India

Dr. P.M. Sureshan, Zoological Survey of India, Kozhikode, Kerala, India

Dr. R. Varatharajan, Manipur University, Imphal, Manipur, India

Dr. Eduard Vives, Museu de Ciències Naturals de Barcelona, Terrassa, Spain

Dr. James Young, Hong Kong Lepidopterists' Society, Hong Kong

Dr. R. Sundararaj, Institute of Wood Science \& Technology, Bengaluru, India

Dr. M. Nithyanandan, Environmental Department, La Ala Al Kuwait Real Estate. Co. K.S.C.,

Kuwait

Dr. Himender Bharti, Punjabi University, Punjab, India

Mr. Purnendu Roy, London, UK

Dr. Saito Motoki, The Butterfly Society of Japan, Tokyo, Japan

Dr. Sanjay Sondhi, TITLI TRUST, Kalpavriksh, Dehradun, India

Dr. Nguyen Thi Phuong Lien, Vietnam Academy of Science and Technology, Hanoi, Vietnam

Dr. Nitin Kulkarni, Tropical Research Institute, Jabalpur, India

Dr. Robin Wen Jiang Ngiam, National Parks Board, Singapore

Dr. Lional Monod, Natural History Museum of Geneva, Genève, Switzerland.

Dr. Asheesh Shivam, Nehru Gram Bharti University, Allahabad, India

Dr. Rosana Moreira da Rocha, Universidade Federal do Paraná, Curitiba, Brasi

Dr. Kurt R. Arnold, North Dakota State University, Saxony, Germany

Dr. James M. Carpenter, American Museum of Natural History, New York, USA

Dr. David M. Claborn, Missouri State University, Springfield, USA

Dr. Kareen Schnabel, Marine Biologist, Wellington, New Zealand

Dr. Amazonas Chagas Júnior, Universidade Federal de Mato Grosso, Cuiabá, Brasil

Mr. Monsoon Jyoti Gogoi, Assam University, Silchar, Assam, India

Dr. Heo Chong Chin, Universiti Teknologi MARA (UiTM), Selangor, Malaysia

Dr. R.J. Shiel, University of Adelaide, SA 5005, Australia

Dr. Siddharth Kulkarni, The George Washington University, Washington, USA

Dr. Priyadarsanan Dharma Rajan, ATREE, Bengaluru, India

Dr. Phil Alderslade, CSIRO Marine And Atmospheric Research, Hobart, Australia

Dr. John E.N. Veron, Coral Reef Research, Townsville, Australia

Dr. Daniel Whitmore, State Museum of Natural History Stuttgart, Rosenstein, Germany.

Dr. Yu-Feng Hsu, National Taiwan Normal University, Taipei City, Taiwan

Dr. Keith V. Wolfe, Antioch, California, USA

Dr. Siddharth Kulkarni, The Hormiga Lab, The George Washington University, Washington,

D.C., USA

Dr. Tomas Ditrich, Faculty of Education, University of South Bohemia in Ceske

Budejovice, Czech Republic

Dr. Mihaly Foldvari, Natural History Museum, University of Oslo, Norway

Dr. V.P. Uniyal, Wildlife Institute of India, Dehradun, Uttarakhand 248001, India

Dr. John T.D. Caleb, Zoological Survey of India, Kolkata, West Bengal, India

Dr. Priyadarsanan Dharma Rajan, Ashoka Trust for Research in Ecology and the Environment

(ATREE), Royal Enclave, Bangalore, Karnataka, India

\section{Fishes}

Dr. Neelesh Dahanukar, IISER, Pune, Maharashtra, India

Dr. Topiltzin Contreras MacBeath, Universidad Autónoma del estado de Morelos, México

Dr. Heok Hee Ng, National University of Singapore, Science Drive, Singapore

Dr. Rajeev Raghavan, St. Albert's College, Kochi, Kerala, India

Dr. Robert D. Sluka, Chiltern Gateway Project, A Rocha UK, Southall, Middlesex, UK

Dr. E. Vivekanandan, Central Marine Fisheries Research Institute, Chennai, India

Dr. Davor Zanella, University of Zagreb, Zagreb, Croatia

Dr. A. Biju Kumar, University of Kerala, Thiruvananthapuram, Kerala, India

Dr. Akhilesh K.V., ICAR-Central Marine Fisheries Research Institute, Mumbai Research

Centre, Mumbai, Maharashtra, India

Dr. J.A. Johnson, Wildlife Institute of India, Dehradun, Uttarakhand, India

Amphibians

Dr. Sushil K. Dutta, Indian Institute of Science, Bengaluru, Karnataka, India

Dr. Annemarie Ohler, Muséum national d'Histoire naturelle, Paris, France

\section{Reptiles}

Dr. Gernot Vogel, Heidelberg, Germany

Dr. Raju Vyas, Vadodara, Gujarat, India

Dr. Pritpal S. Soorae, Environment Agency, Abu Dubai, UAE.

Prof. Dr. Wayne J. Fuller, Near East University, Mersin, Turkey

Prof. Chandrashekher U. Rivonker, Goa University, Taleigao Plateau, Goa. India

Dr. S.R. Ganesh, Chennai Snake Park, Chennai, Tamil Nadu, India

Dr. Himansu Sekhar Das, Terrestrial \& Marine Biodiversity, Abu Dhabi, UAE
Birds

Dr. Hem Sagar Baral, Charles Sturt University, NSW Australia

Dr. Chris Bowden, Royal Society for the Protection of Birds, Sandy, UK

Dr. Priya Davidar, Pondicherry University, Kalapet, Puducherry, India

Dr. J.W. Duckworth, IUCN SSC, Bath, UK

Dr. Rajah Jayapal, SACON, Coimbatore, Tamil Nadu, India

Dr. Rajiv S. Kalsi, M.L.N. College, Yamuna Nagar, Haryana, India

Dr. V. Santharam, Rishi Valley Education Centre, Chittoor Dt., Andhra Pradesh, India

Dr. S. Balachandran, Bombay Natural History Society, Mumbai, India

Mr. J. Praveen, Bengaluru, India

Dr. C. Srinivasulu, Osmania University, Hyderabad, India

Dr. K.S. Gopi Sundar, International Crane Foundation, Baraboo, USA

Dr. Gombobaatar Sundev, Professor of Ornithology, Ulaanbaatar, Mongolia

Prof. Reuven Yosef, International Birding \& Research Centre, Eilat, Israel

Dr. Taej Mundkur, Wetlands International, Wageningen, The Netherlands

Dr. Carol Inskipp, Bishop Auckland Co., Durham, UK

Dr. Tim Inskipp, Bishop Auckland Co, Durham, UK

Dr. V. Gokula, National College, Tiruchirappalli, Tamil Nadu, India

Dr. Arkady Lelej, Russian Academy of Sciences, Vladivostok, Russia

Dr. Simon Dowell, Science Director, Chester Zoo, UK

Dr. Mário Gabriel Santiago dos Santos, Universidade de Trás-os-Montes e Alto Douro,

Quinta de Prados, Vila Real, Portugal

Dr. Grant Connette, Smithsonian Institution, Royal, VA, USA

Dr. M. Zafar-ul Islam, Prince Saud Al Faisal Wildlife Research Center, Taif, Saudi Arabia

Mammals

Dr. Giovanni Amori, CNR - Institute of Ecosystem Studies, Rome, Italy

Dr. Anwaruddin Chowdhury, Guwahati, India

Dr. David Mallon, Zoological Society of London, UK

Dr. Shomita Mukherjee, SACON, Coimbatore, Tamil Nadu, India

Dr. Angie Appel, Wild Cat Network, Germany

Dr. P.O. Nameer, Kerala Agricultural University, Thrissur, Kerala, India

Dr. Ian Redmond, UNEP Convention on Migratory Species, Lansdown, UK

Dr. Heidi S. Riddle, Riddle's Elephant and Wildlife Sanctuary, Arkansas, USA

Dr. Karin Schwartz, George Mason University, Fairfax, Virginia.

Dr. Lala A.K. Singh, Bhubaneswar, Orissa, India

Dr. Mewa Singh, Mysore University, Mysore, India

Dr. Paul Racey, University of Exeter, Devon, UK

Dr. Honnavalli N. Kumara, SACON, Anaikatty P.O., Coimbatore, Tamil Nadu, India

Dr. Nishith Dharaiya, HNG University, Patan, Gujarat, India

Dr. Spartaco Gippoliti, Socio Onorario Società Italiana per la Storia della Fauna "Giuseppe

Altobello", Rome, Italy

Dr. Justus Joshua, Green Future Foundation, Tiruchirapalli, Tamil Nadu, India

Dr. H. Raghuram, The American College, Madurai, Tamil Nadu, India

Dr. Paul Bates, Harison Institute, Kent, UK

Dr. Jim Sanderson, Small Wild Cat Conservation Foundation, Hartford, USA

Dr. Dan Challender, University of Kent, Canterbury, UK

Dr. David Mallon, Manchester Metropolitan University, Derbyshire, UK

Dr. Brian L. Cypher, California State University-Stanislaus, Bakersfield, CA

Dr. S.S. Talmale, Zoological Survey of India, Pune, Maharashtra, India

Prof. Karan Bahadur Shah, Budhanilakantha Municipality, Kathmandu, Nepal

Dr. Susan Cheyne, Borneo Nature Foundation International, Palangkaraja, Indonesia

Dr. Hemanta Kafley, Wildlife Sciences, Tarleton State University, Texas, USA

\section{Other Disciplines}

Dr. Aniruddha Belsare, Columbia MO 65203, USA (Veterinary)

Dr. Mandar S. Paingankar, University of Pune, Pune, Maharashtra, India (Molecular)

Dr. Jack Tordoff, Critical Ecosystem Partnership Fund, Arlington, USA (Communities)

Dr. Ulrike Streicher, University of Oregon, Eugene, USA (Veterinary)

Dr. Hari Balasubramanian, EcoAdvisors, Nova Scotia, Canada (Communities)

Dr. Rayanna Hellem Santos Bezerra, Universidade Federal de Sergipe, São Cristóvão, Brazil

Dr. Jamie R. Wood, Landcare Research, Canterbury, New Zealand

Dr. Wendy Collinson-Jonker, Endangered Wildlife Trust, Gauteng, South Africa

Dr. Rajeshkumar G. Jani, Anand Agricultural University, Anand, Gujarat, India

Dr. O.N. Tiwari, Senior Scientist, ICAR-Indian Agricultural Research Institute (IARI), New

Delhi, India

Dr. L.D. Singla, Guru Angad Dev Veterinary and Animal Sciences University, Ludhiana, India

Dr. Rupika S. Rajakaruna, University of Peradeniya, Peradeniya, Sri Lanka

Dr. Bahar Baviskar, Wild-CER, Nagpur, Maharashtra 440013, India

Reviewers 2018-2020

Due to pausity of space, the list of reviewers for $2018-2020$ is available online.

The opinions expressed by the authors do not reflect the views of the Journal of Threatened Taxa, Wildlife Information Liaison Development Society, Zoo Outreach Organization, or any of the partners. The journal, the publisher, the host, and the partners are not responsible for the accuracy of the political boundaries shown in the maps by the authors.

Journal of Threatened Taxa is indexed/abstracted in Bibliography of Systematic Mycology, Biological Abstracts, BIOSIS Previews, CAB Abstracts, EBSCO, Google Scholar, Index Copernicus, Index Fungorum, JournalSeek, National Academy of Agricultural Sciences, NewJour, OCLC WorldCat, SCOPUS, Stanford University Libraries, Virtual Library of Biology, Zoological Records.

NAAS rating (India) 5.64
Print copies of the Journal are available at cost. Write to:

The Managing Editor, JoTT,

c/o Wildlife Information Liaison Development Society,

No. 12, Thiruvannamalai Nagar, Saravanampatti - Kalapatti Road,

Saravanampatti, Coimbatore, Tamil Nadu 641035, India

ravi@threatenedtaxa.org 


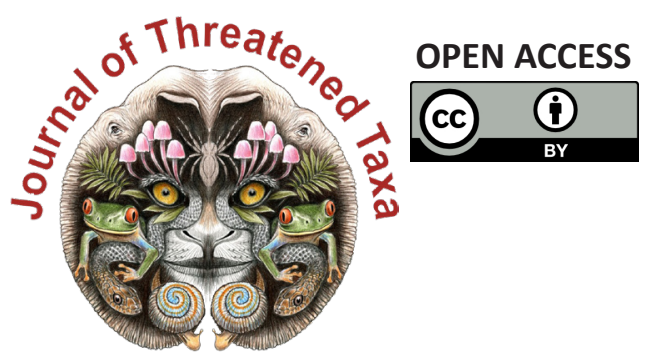

www.threatenedtaxa.org

The Journal of Threatened Taxa (JoTT) is dedicated to building evidence for conservation globally by publishing peer-reviewed articles online every month at a reasonably rapid rate at www.threatenedtaxa.org. All articles published in JoTT are registered under Creative Commons Attribution 4.0 International License unless otherwise mentioned. JoTT allows allows unrestricted use, reproduction, and distribution of articles in any medium by providing adequate credit to the author(s) and the source of publication.

\section{ISSN $0974-7907$ (Online) | ISSN $0974-7893$ (Print)}

\section{January 2022 | Vol. 14 | No. 1 | Pages: 20311-20538 \\ Date of Publication: 26 January 2022 (Online \& Print) DOI: 10.11609/jott.2022.14.1.20311-20538}

Articles

Estimating the completeness of orchid checklists and atlases: a case study from southern Italy

- Antonio Croce, Pp. 20311-20322

A floristic survey across three coniferous forests of Kashmir Himalaya, India - a checklist

- Ashaq Ahmad Dar, Akhtar Hussain Malik \& Narayanaswamy Parthasarathy, Pp. 20323-20345

Associations of butterflies across different forest types in Uttarakhand, western Himalaya, India: implications for conservation planning

- Arun Pratap Singh, Pp. 20346-20370

Comparison of bird diversity in protected and non-protected wetlands of western lowland of Nepal

- Jagan Nath Adhikari, Janak Raj Khatiwada, Dipendra Adhikari, Suman Sapkota, Bishnu Prasad Bhattarai, Deepak Rijal \& Lila Nath Sharma, Pp. 20371-20386

Local hunting practices and perceptions regarding the distribution and ecological role of the Large Flying Fox (Chiroptera: Pteropodidae: Pteropus vampyrus) in western Sarawak, Malaysian Borneo

- Jayasilan Mohd-Azlan, Joon Yee Yong, Nabila Norshuhadah Mohd Hazzrol, Philovenny Pengiran, Arianti Atong \& Sheema Abdul Aziz, Pp. 20387-20399

\section{Communications}

Macrolichens of Mathikettan Shola National Park, Western Ghats: a preliminary investigation with some new records

- Aswathi Anilkumar, Stephen Sequeira, Arun Christy \& S.M. Arsha, Pp. 20400-20405

New distribution record of globally threatened Ocean Turf Grass Halophila beccarii Ascherson, 1871 from the North Andaman Islands highlights the importance of seagrass exploratory surveys

- Swapnali Gole, Prasad Gaidhani, Srabani Bose, Anant Pande, Jeyaraj Antony Johnson \& Kuppusamy Sivakumar, Pp. 20406-20412

An inventory of new orchid (Orchidaceae) records from Kozhikode, Kerala, India - M. Sulaiman, C. Murugan \& M.U. Sharief, Pp. 20413-20425

Abundance and spatial distribution analyses of Stemonoporus moonii Thwaites (Dipterocarpaceae) - a critically endangered species endemic to Sri Lanka - K.A.M.R.P. Atapattu, H.D.D.C.K. Perera, H.S. Kathriarachchi \& A.R. Gunawardena, Pp. 20426-20432

Plant diversity of Point Calimere Wildlife Sanctuary and fodder species grazed by the Blackbuck Antilope cervicapra L.

- Ashutosh Kumar Upadhyay, A. Andrew Emmanuel, Ansa Sarah Varghese \&

D. Narasimhan, Pp. 20433-20443

Raptors observed (1983-2016) in National Chambal Gharial Sanctuary: semi-arid biogeographic region suggestions for parametric studies on ecological continuity in Khathiar-Gir Ecoregion, India

- L.A.K. Singh, R.K. Sharma \& Udayan Rao Pawar, Pp. 20444-20460

Nesting success of Sharpe's Longclaw (Macronyx sharpei Jackson, 1904) around the grasslands of lake Ol'bolossat Nyandarua, Kenya

- Hamisi Ann Risper, Charles M. Warui \& Peter Njoroge, Pp. 20461-20468

Population, distribution and diet composition of Smooth-coated Otter Lutrogale perspicillata Geoffroy, 1826 in Hosur and Dharmapuri Forest Divisions, India - Nagarajan Baskaran, Raman Sivaraj Sundarraj \& Raveendranathanpillai Sanil, Pp. 20469-20477

Utilization of home garden crops by primates and current status of human-primate interface at Galigamuwa Divisional Secretariat Division in Kegalle District, Sri Lanka

- Charmalie Anuradhie Dona Nahallage, Dahanakge Ayesha Madushani Dasanayake, Dilan Thisaru Hewamanna \& Dissanayakalage Tharaka Harshani Ananda, Pp. 2047820487
Revival of Eastern Swamp Deer Rucervus duvaucelii ranjitsinhi (Groves, 1982) in Manas National Park of Assam, India

- Nazrul Islam, Aftab Ahmed, Rathin Barman, Sanatan Deka, Bhaskar Choudhury, Prasanta Kumar Saikia \& Jyotishman Deka, Pp. 20488-20493

Trypanosoma evansi infection in a captive Indian Wolf Canis lupus pallipes - molecular diagnosis and therapy

- Manojita Dash, Sarat Kumar Sahu, Santosh Kumar Gupta, Niranjana Sahoo \& Debarat Mohapatra, Pp. 20494-20499

View Point

COVID-19 and civil unrest undoing steady gains in karst conservation and herpetological research in Myanmar, and an impediment to progress - Evan S.H. Quah, Lee L. Grismer, Perry L. Wood, Jr., Aung Lin \& Myint Kyaw Thura, Pp. 20500-20502

\section{Short Communications}

Morphological characterization and mt DNA barcode of a tiger moth species, Asota ficus (Fabricius, 1775) (Lepidoptera: Noctuoidea: Erebidae: Aganainae) from India - Aparna Sureshchandra Kalawate, K.P. Dinesh \& A. Shabnam, Pp. 20503-20510

Distribution of Smooth-coated Otters Lutrogale perspicillata (Mammalia: Carnivora: Mustelidae): in Ratnagiri, Maharashtra, India

- Swanand Patil \& Kranti Yardi, Pp. 20511-20516

Wildlife at the crossroads: wild animal road kills due to vehicular collision on a mountainous highway in northwestern Himalayan region

- Muzaffar A. Kichloo, Asha Sohil \& Neeraj Sharma, Pp. 20517-20522

Notes

Robiquetia gracilis (Lindl.) Garay-a new record to the flora of Anamalai Hills, Tami Nadu, India

- B. Subbaiyan, V. Ganesan, P.R. Nimal Kumar \& S. Thangaraj Panneerselvam, Pp. 20523-20525

Ipomoea laxiflora H.J. Chowdhery \& Debta (Convolvulaceae): new records for the Western Ghats and semiarid regions

- Sachin M. Patil, Ajit M. Vasava, Vinay M. Raole \& Kishore S. Rajput, Pp. 20526-20529

Counting the cost: high demand puts Bunium persicum (Boiss.) B.Fedtsch. in jeopardy

- Monika Sharma, Manisha Mathela, Rupali Sharma, Himanshu Bargali, Gurinderjit S Goraya \& Amit Kumar, Pp. 20530-20533

First record of Parasitic Jaeger Stercorarius parasiticus (Aves: Charadriiformes: Stercorariidae) from inland freshwater Inle Lake, Myanmar

- Sai Sein Lin Oo, Myint Kyaw, L.C.K. Yun, Min Zaw Tun, Yar Zar Lay Naung, Soe Naing Aye \& Swen C. Renner, Pp. 20534-20536

\section{Book Review}

Capparis of India

- V. Sampath Kumar, Pp. 20537-20538
Publisher \& Host


Threatened Taxa 